\title{
Outsourcing, Income Distribution, and Unemployment
}

\author{
Shigemi Yabuuchi \\ Aichi University
}

\begin{abstract}
This paper examines the effects of outsourcing on employment and unemployment and income distribution in an economy with Harris-Todaro type unemployment. This is because both wages and jobs are important concerns for an economy that engages in outsourcing and consequently experiences widespread unemployment. The main findings of this paper are as follows: (i) If the outsourced factor is not produced domestically, outsourcing increases the rural wage rate (and the expected urban wage rate) and decreases the unemployed-to-employed ratio in the urban area, and it may increase unemployment in the home country. (ii) If the outsourced factor is produced domestically, outsourcing may decrease the rural wage rate (and the expected urban wage rate), and may increase the unemployedto-employed ratio in the urban area if the rural wage rate is not sensitive to the employment in the rural sectors.
\end{abstract}

- JEL Classification: F18, F23, J31, O18

- Keywords: Outsourcing, Unemployment, Income distribution

\section{Introduction}

Outsourcing or offshoring has been a vital business strategy in many advanced countries, such as the US, the EU, and Japan, since the early 1990s, and has recently been adopted in the NIES and emerging economies as well. Generally speaking, outsourcing is defined as firms' behavior of subcontracting some

\footnotetext{
*Corresponding address: Shigemi Yabuuchi; Faculty of Economics, Aichi University, Machihata, Toyohashi, Aichi 441-8522, Japan, E-mail: yabuuchi@aichi-u.ac.jp, Tel: 81-532-47-4111, Fax:81-53247-4132

(C2011-Center for Economic Integration, Sejong Institution, Sejong University, All Rights Reserved.
} 
processes in their production to other firms abroad, mainly in low-wage developing economies, in order to attain higher productivity, efficiency, and profitability. That is, outsourced inputs, goods, and services enhance a firm's capacity to participate in an increasingly competitive world economy. This in turn has the potential to increase overall efficiency in the economy and improve welfare. Thus, extensive outsourcing has assumed even greater significance for developed countries, especially those like the US and Japan, which are experiencing high-wage domestic labor. Therefore, the spread of outsourcing and exploiting low-wage workers have been top priorities in some developed economies. There has been an argument that outsourcing is just another way of doing international trade and must be beneficial to the nation, including the workers. Batra and Beladi (2010a) called this the Mankiw-Yellen hypothesis. On the other hand, negative relations between outsourcing and employment in the U.S. are reported by, for example, Bardhan and Kroll (2003) and Burke et al. (2004).

Jones (2005) shows that immigration and outsourcing may serve to raise the wage rate of domestic labor in the home country. However, the effects of outsourcing on the labor market are both ambiguous and substantial, as suggested by Egger and Egger (2005). Thus, outsourcing may be harmful to domestic labor in terms of wages, jobs, or both under some circumstance even if it is beneficial to the economy as a whole. Kohler (2001) presents an alternative view on international fragmentation based on the specific-factors model. He shows that international outsourcing may cause a welfare loss. Various aspects of outsourcing, especially in relation to the labor market, have been discussed extensively. Deardorff (2005) attempts to explain the phenomenon of skilled-worker outsourcing. Long (2005) develops a model to explain incomplete outsourcing in the presence of the spillover benefit of training. Keuschnigg and Ribi (2009) investigate the consequences of outsourcing on the labor market and derive the welfare optimal redistribution and unemployment insurance policies. Recently, Batra and Beladi (2010a) explored the impact of outsourcing on factor prices by using a simple two-sector, specific-factor model with outsourced intermediate inputs. They found that "outsourcing may hurt domestic labor, while it definitely benefits capital; but it may actually be beneficial to labor, if there is no production of outsourced work at home at all." However, almost all of these studies assume full employment of labor, except for Keuschnigg and Ribi (2009), which deal with 
unemployment insurance. ${ }^{1}$ Then, in this paper, we focus our attention on the other aspect of labor market and examine the effect of outsourcing on employment and unemployment and income distribution, because both wages and jobs are important concerns for an economy that engages in outsourcing. For this purpose, we introduce unemployment a la Harris-Todaro into the standard specific-factor model, using the intermediate input explored by Batra and Beladi. The HarrisTodaro framework has been utilized extensively in development and trade literature. $^{2}$

The main findings of this paper are as follows: (i) If the outsourced factor is not produced domestically, outsourcing increases the rural wage rate (and the expected urban wage rate) and decreases the unemployed-to-employed ratio in the urban area, and it may increase unemployment in the home country. (ii) If the outsourced factor is produced domestically, outsourcing may decrease the rural wage rate (and the expected urban wage rate) and may increase the unemployed-to-employed ratio in the urban area if the rural wage rate is not sensitive to the employment in the rural sectors. The precise conditions for the paradoxical results are derived and interpreted on economic principles.

The rest of the paper is organized as follows. In section II, we present the basic model and assumptions. Section III provides the results from comparative static analyses on income distribution and unemployment in the model without domestic production of outsourced factors, whereas section IV explores the effects of outsourcing in the model with domestic production of outsourced factors. Section $\mathrm{V}$ provides some concluding remarks.

\section{The Model}

Following Batra and Beladi (2010a), we consider a small open economy that comprises two sectors- the importable goods sector $X$ and the exportable goods sector $Y$. Sector $X$ uses three factors, capital, labor, and the product of an outsourced factor, $V$; that is, the producers in sector $X$ engage in outsourcing. They produce

\footnotetext{
${ }^{1}$ Zhu (2008) provides a comprehensive literature review on the labor market outcome of international trade and outsourcing. See also Feenstra and Hanson (1996), Gorg and Hanley (2005), Tomiura (2005), Swenson (2005), Kierzkowski (2005), Grossman and Helpman (2005), and Batra and Beladi (2010b), among others.

${ }^{2}$ See, for example, Harris and Todaro (1970), Bhagwati and Srinivasan (1974), Khan (1980), Neary (1981), Yabuuchi (1993), Gupta (1993), Chao and Yu (1996), Basu (2000), Marjit and Beladi (2003), Beladi and Yabuuchi (2010).
} 
various kinds of intermediate goods or services with the aid of a subcontractor located in a foreign country. In this section, we consider the case of a producer who has no domestic production of the outsourced factor, and in the following section, we consider a general case where the outsourced factor is produced also in the home country.

On the other hand, production of an exportable good and the intermediate factor require only labor and capital. We suppose that sector $X$ produces a manufacturing good, while sector $Y$ produces an agricultural good. Thus, the linearly homogeneous production functions of the manufacturing sector, $X$, and the agricultural sector, $Y$, are given as follows:

$$
\begin{gathered}
X=X\left(L_{x}, K_{x}, V_{x}\right), \\
Y=Y\left(L_{y}, K_{y}\right),
\end{gathered}
$$

where $K_{j}$ and $L_{j}$ represent employment of capital and labor in the $i$ th sector $(i=X$, $Y$ ), and $V_{x}$ is the outsourced factor used in sector $X$. It is supposed that capital is specific to each sector, following Jones (1971).

We concentrate mainly on the effects of outsourcing on income distribution and unemployment in the home country. We assume that the agricultural good $(Y)$ is exported and is numeraire, so that its price equals unity and it is the base good, while the manufacturing good $(X)$ is an importable good with world price $p$.

There are two areas in the economy, a rural area and an urban area. We suppose that the intermediate sector, as well as the agricultural sector, is located in the rural area while the manufacturing sector is located in the urban area. Following Harris and Todaro (1970), it is assumed that the real wage rate in the manufacturing sector $\left(w_{x}\right)$ is rigid due to certain political and/or institutional considerations, while the wage rate in the agricultural sector and the outsourced sector $(w)$ is flexible. The characteristic feature of the original Harris-Todaro (HT) model is that in the labor market equilibrium, the rural wage rate ( $w$ ) equals the expected wage income in the urban manufacturing sector, which is by definition the manufacturing wage rate $\left(w_{x}\right)$ multiplied by the probability of finding a job in the manufacturing sector. Let $L_{u}$ represent the unemployed in the urban area. Since the probability of finding a job in the manufacturing sector is $L_{x} /\left(L_{x}+L_{u}\right)$, the expected wage income in the manufacturing sector is $w_{x} L_{x} /\left(L_{x}+L_{u}\right)$. Thus, the labor allocation mechanism between rural and urban areas is expressed as $w_{x} L_{x} /\left(L_{x}+L_{u}\right)=w$. This can also be 
expressed as

$$
w_{x}=(1+\lambda) w
$$

where

$$
\lambda=L_{u} / L_{x}
$$

Here, $\lambda$ is the unemployed-employed ratio in sector $X$.

The labor market equilibrium is expressed, in addition to (3) above, as

$$
\begin{gathered}
w_{x}=p X_{L}\left(L_{x}, K_{x}, V_{x}\right), \\
w=Y_{L}\left(L_{y}, K_{y}\right)
\end{gathered}
$$

Foreign firms charge its price, $b^{*}$, for their service or intermediate product, and the producers in sector $X$ employ the factor until the marginal value product of the factor equals its price. Thus, we have

$$
b^{*}=p X_{v}\left(L_{x}, K_{x}, V_{x}\right)
$$

In the capital markets, the reward for capital is determined in the two sectors as

$$
\begin{gathered}
r_{x}=p X_{K}\left(L_{x}, K_{x}, V_{x}\right), \\
r_{y}=Y_{K}\left(L_{y}, K_{y}\right) .
\end{gathered}
$$

The labor employment condition in the home country is represented as

$$
(1+\lambda) L_{x}+L_{y}=L
$$

This completes the specification of our model. We have eight unknown variables- $r_{x}, r_{y}, w, \lambda, L_{u}, L_{x}, L_{y}$, and $V_{x}$ - that are solved by eight equations, (3)(10), for the given parameters, $w_{x}, p, b^{*}, K_{x}, K_{y}$ and $L$. 


\section{Unemployment and Income Distribution without Domestic Production}

Note that the effect of outsourcing is represented by a fall in the relative price of the intermediate good or service, that is, $b^{*}$. This leads to an increased use of outsourcing, whatever the reason. This is the approach suggested by Mankiw et al. (2004). Then, let us first differentiate (3)-(10) and solve the system for the changes in the key variables with respect to the change in the price of the outsourced factor, $b^{*}$; we have (see Appendix 1)

$$
d \lambda / d b^{*}=-(1+\lambda)^{2} Y_{L L} p X_{L V} / \Delta>0,
$$

where

$$
\begin{aligned}
& \Delta=\left\{w-L_{x}(1+\lambda) Y_{L L}\right\} H>0, \\
& H=p X_{L L} p X_{V V}-\left(p X_{L V}\right)>0 .
\end{aligned}
$$

Here, $\Delta$ is the value of the determinant of the coefficient matrix of the equation system, which can be shown to be positive because of the property of the production function in sector $X$, as shown in the definition of $H$.

Thus, the following proposition follows directly from (3) and (11).

Proposition 1. In an economy without domestic production of outsourced factors, outsourcing decreases the unemployed-to-employed ratio in the urban area and increases the rural (and expected urban) wage rate.

Outsourcing expands the production of sector $X$ by increasing the import and use of the outsourced factor. This raises the expected wage income in the urban manufacturing sector and induces the inflow of labor from the rural to the urban area. The decrease in rural labor will push up the rural wage rate, that is, the "average" wage rate in the economy.

Some of the migrant workers are employed in sector $X$, and others are absorbed in the unemployment pool. The necessary labor in the manufacturing sector is also supplied from this unemployment pool. Thus, the effect on unemployment itself is indeterminate, and the number of unemployed workers may increase. However, our 
result shows that the increase in employment in sector $X$ is greater than that in unemployment even if unemployment does increase. We will discuss in detail the effect of outsourcing on the level of urban unemployment later.

Now, let us turn to the effect of outsourcing on the rental of capital in each sector. We obtain the change in the employment of the sectors as follows (see Appendix 1):

$$
\begin{gathered}
d L_{x} / d b^{*}=\left\{L_{x}(1+\lambda) Y_{L L}-w\right\} p X_{L V} / \Delta<0, \\
d L_{y} / d b^{*}=(1+\lambda) w p X_{L V} / \Delta>0, \\
d V_{x} / d b^{*}=\left\{w-L_{x}(1+\lambda) Y_{L L}\right\} p X_{L L} / \Delta<0 .
\end{gathered}
$$

Thus, it is obvious that

$$
\begin{gathered}
d r_{x} / d b^{*}=p X_{K L}\left(d L_{x} / d b^{*}\right)+p K_{K V}\left(d V_{x} / d b^{*}\right)<0, \\
d r_{y} / d b^{*}=Y_{K L}\left(d L_{y} / d b^{*}\right)>0 .
\end{gathered}
$$

Thus, capital in sector $X$ benefits, and that in sector $Y$ suffers from increased outsourcing. These results show the robustness of those obtained by Batra and Beladi (2010a) in the model without domestic production.

Finally, let us focus on the level (not the rate) of unemployment. We are interested in the changes in employment and unemployment due to outsourcing. Thus, from (12) and (13), we have

$$
\left(d L_{x} / d b^{*}\right)+\left(d L_{y} / d b^{*}\right)=w p X_{L V}\left\{\lambda-L_{x}(1+\lambda) \xi_{L L}^{Y} / L_{y}\right\} / \Delta .
$$

The result is summarized in the following proposition.

Proposition 2. In an economy without domestic production of outsourced factors, outsourcing increases total employment (decreases unemployment) if and only if $\xi_{L L}^{Y}>\mu L_{y} / L_{x}$, where $\mu=\lambda /(1+\lambda)=L_{u} /\left(L_{x}+L_{u}\right)$.

The condition will be satisfied if either the rural employment is inelastic to the change in the rural wage rate (i.e., large $\xi_{L L}^{Y}$ ) or the initial level of urban 
unemployment is low. Outsourcing induces the import of the intermediate good or service from foreign subcontract firms. This expands the production of sector $X$ and in turn increases employment in the sector. Some of the necessary workers are absorbed from the urban unemployment pool, and others are supplied from the rural area. Rural workers move from the rural area to the urban area in response to an increase in the expected urban wage rate. The movement of labor is limited if the rural workers are not sensitive to the change in wage rate or, in other words, the elasticity of the rural wage rate with respect to employment $\left(\xi_{L L}^{Y}\right)$ is high. This will happen if rural workers find their lives in the rural area comfortable because of stability, the presence of family and friends, and so on. In these circumstances, they do not want to move to the urban area unless the increase in the expected wage income is considerably large.

On the other hand, a large number of workers move to the urban areas if they are sensitive to the increase in the expected urban wage income (i.e., $\xi_{L L}^{Y}$ is low). Some of them are employed successfully, but others are unemployed, in sector $X$. If the number of workers left in the rural area is larger than that employed in sector $X$, unemployment increases.

\section{Outsourcing and Income Distribution with Domestic Production}

The assumption that the outsourced factor is not produced in the home country is rather unrealistic. In this section, we introduce the domestic production of the factor and generalize the analysis. The linearly homogeneous production function of the intermediate sector, $V$, is given as follows:

$$
V=V\left(L_{v}, K_{v}\right)
$$

where $K_{v}$ and $L_{v}$ represent employment of capital and labor, respectively, in sector $V$. Thus, since the intermediate input $V_{x}$ now consists of outsourced factors from foreign and domestic firms, we have

$$
V_{x}=V\left(L_{v}, K_{v}\right)+V^{*},
$$

where $V^{*}$ is the intermediate factor from abroad. 
We suppose that the domestic subcontract firms are located in the rural area. ${ }^{3}$ Then, the labor market equilibrium in the rural area is expressed as

$$
w=Y_{L}\left(L_{y}, K_{y}\right)=b^{*} V_{L}\left(L_{v}, K_{v}\right)
$$

In the capital markets, the reward for capital is also determined in the intermediate sector as

$$
r_{v}=V_{K}\left(L_{v} K_{v}\right)
$$

Now, the labor employment condition in the home country is represented as

$$
(1+\lambda) L_{x}+L_{y}+L_{v}=L
$$

This completes the specification of our model with domestic production of the outsourced factor. We have ten unknown variables $-r_{x}, r_{y}, r_{v}, w, \lambda, L_{u}, L_{x}, L_{y}, L_{v}$, and $V^{*}$ - that are solved by ten equations, (3)-(5), (7)-(9), and (20)-(22), for the given parameters, $w_{x}, p, b^{*}, K_{x}, K_{y}, K_{v}$, and $L^{4}$

Totally differentiating the equations and solving them for the key equations, we obtain (see Appendix 2):

$$
\begin{gathered}
d \lambda / d b^{*}=-(1+\lambda) Y_{L L}\left\{(1+\lambda) p X_{L V} b^{*} V_{L L}+V_{L} H\right\} / \Omega, \\
d L_{x} / d b^{*}=p X_{L V}\left\{L_{x}(1+\lambda) Y_{L L} b^{*} V_{L L}-w\left(Y_{L L}+b^{*} V_{L L}\right)\right\} / \Omega<0, \\
d L_{y} / d b^{*}=w\left\{(1+\lambda) p X_{L V} b^{*} V_{L L}+V_{L} H\right\} / \Omega, \\
d L_{\vee} / d b^{*}=\left[\left\{L_{x}(1+\lambda) Y_{L L}-w\right\} V_{L} H+(1+\lambda) w p X_{L V} Y_{L L}\right] / \Omega>0, \\
d V^{*} / d b^{*}=-\left[\left\{L_{x}(1+\lambda) Y_{L L}-w\right\} V_{L}^{2} H+V_{L}(1+\lambda) w p X_{L V} Y_{L L}\right. \\
\left.+p X_{L L}\left\{L_{x}(1+\lambda) Y_{L L} b^{*} V_{L L}-w\left(Y_{L L}+b^{*} V_{L L}\right)\right\}\right] / \Omega<0 .
\end{gathered}
$$

where

\footnotetext{
${ }^{3}$ It will not be very unrealistic to assume that the wage rate in the intermediate sector is the same as the rural wage rate. The geographical location is not important, and the sector may be in the urban area. ${ }^{4}$ Note that (20) contains two equations.
} 


$$
\left.\Omega=\left\{w\left(Y_{L L}+b^{*} V_{L L}\right)\right\}-L_{x}(1+\lambda) Y_{L L} b^{*} V_{L L}\right\}<0 .
$$

Here, $\Omega$ is the value of the determinant of the coefficient matrix of the equation system with the domestic production of the outsourced factor, which can be shown to be negative because of the property of the production functions in sectors $Y$ and $V$.

Thus, from (23), we have following proposition.

Proposition 3. In an economy with domestic production of outsourced factors, outsourcing decreases the unemployed-to-employed ratio in the urban area and increases the rural (and expected urban) wage rate if and only if $\xi_{L L}^{V} \xi_{L V}^{X}$ $>L_{v} V_{x} H /(1+\lambda) w_{x} b^{*}$, where $\xi_{L L}^{V}=-L_{v} b^{*} V_{L L} / w$ and $\xi_{L V}^{X}=V_{x} P V_{L V} / w_{x}$.

It can be seen from (19), (26), and (27) that

$$
\begin{gathered}
\left(d V_{x} / d b^{*}\right)=V_{L}\left(d L_{v} / d b^{*}\right)+\left(d V^{*} / d b^{*}\right) \\
=-p X_{L L}\left\{L_{x}(1+\lambda) Y_{L L} b^{*} V_{L L}-w\left(Y_{L L}+b^{*} V_{L L}\right)\right\} / \Omega<0
\end{gathered}
$$

Thus, increased outsourcing expands the production and use of the outsourced factor in sector $X$. This increases urban employment due to the increase in the value of the marginal product of labor in the sector. The higher the cross-elasticity $\left(\xi_{L V}^{X}\right)$, the greater is the increase in employment.

On the other hand, in the rural area, it can be seen from (25) and (26) that the employment in sector $V$ decreases definitely, while the change in sector $Y$ is ambiguous. The employment in sector $V$ decreases due to the rural-urban allocation a la Harris-Todaro as well as the decrease in the marginal value product of labor $\left(b^{*} V_{L}\right)$. The former effect is captured by the movement along the marginal value product curve, while the latter is captured by the shift of the curve itself. Anyway, it can be shown that both effects will be small if the own elasticity of the rural wage rate $\left(\xi_{L L}^{V}\right)$ is high, that is, if the workers in sector $V$ are not sensitive to the change in the rural wage rate. In this case, therefore, a relatively small decrease of employment occurs in sector $V$, while urban employment increases leading to a possible decrease in unemployment. However, the change in unemployment is still ambiguous partly because the employment in sector $Y$ also decreases under the same condition stated in Proposition 3, as shown by (23) and (25). Unemployment may increase or decrease depending on the increase in the urban employment relative to the decrease in the rural employment. Our result shows that, even if 
unemployment rises, its increase is less than that of urban employment under the condition in Proposition 3. This implies that the urban unemployed-to-employed ratio $(\lambda)$ decreases, and then the wage rate increases since the increase in the ratio lowers the expected wage income in the urban manufacturing sector. This result has an important implication for a change in the home country GDP, as discussed below.

Now let us examine the effect of outsourcing on employment and unemployment. We obtain from (24), (25), and (26)

$$
\begin{aligned}
& \left(d L_{x} / d b^{*}\right)+\left(d L_{y} / d b^{*}\right)+\left(d L_{v} / d b^{*}\right) \\
& =(1+\lambda)\left\{w p X_{L V} b^{*} V_{L L}\left(\mu-\xi_{L L}^{Y}\right)+Y_{L L}\left(L_{x}+\mu w p X_{L V}\right)\right\} / \Omega
\end{aligned}
$$

where $\mu=\lambda /(1+\lambda)=L_{u} /\left(L_{x}+L_{u}\right)$, and it is the unemployment rate in the urban area.

This shows that there is a paradoxical possibility, and the result is summarized in the following proposition.

\section{Proposition 4. In an economy with domestic production of outsourced} factors, outsourcing decreases total employment (increases unemployment) if the elasticity of the rural wage rate with respect to the employment is lower than the urban unemployment rate, i.e., $\xi_{L L}^{Y}<\mu$.

As discussed above, outsourcing increases urban employment and decreases employment in sector $V$, while the change in employment in sector $Y$ is ambiguous. Thus, the latter effect is critical to the total effect of outsourcing on employment of the whole economy. If the rural workers in sector $Y$ are very sensitive to the wage rate, then they move to urban areas in large numbers in response to even a small increase in the expected urban wage income. In this sense, therefore, the decrease in employment in sector $Y$ (as well as that in sector $V$ ) becomes dominant, and the total employment decreases eventually. This implies that outsourcing increases urban unemployment. Proposition 4 provides a sufficient condition for the result.

Let us now examine how the reward for capital behaves in each sector due to increased outsourcing. It can be seen from (24)-(27) that

$$
\begin{gathered}
d r_{x} / d b^{*}=p X_{K L}\left(d L_{x} / d b^{*}\right)+p X_{K \nu}\left(d V_{x} / d b^{*}\right)<0, \\
d r_{y} / d b^{*}=Y_{K L}\left(d L_{y} / d b^{*}\right),
\end{gathered}
$$




$$
d r_{\vee} / d b^{*}=V_{K L}\left(d L_{\Downarrow} / d b^{*}\right)>0 .
$$

With no domestic production of outsourced factors, capital in sector $X$ benefits from increased outsourcing. In the present case, however, capital in the outsourced sector $V$ suffers definitely, and the change in capital in sector $Y$ is ambiguous. This is partly because labor moves from rural to urban areas according to the Harris-Todaro labor allocation mechanism. Further, the change in capital reward in sector $Y$ exactly follows the condition in Proposition 3 (i.e., $\left.\xi_{L L}^{V} \xi_{L V}^{X}>L_{v} V_{x} H /(1+\lambda) w_{x} b^{*}\right)$ and is interpreted thus.

Finally, the effect of outsourcing on real GDP is noteworthy. As regards real GDP, it is shown as follows:

$$
Z=p X+Y-b^{*} V^{*} .
$$

Differentiating (27) yields

$$
d Z / d b^{*}=-L_{x}\left(d \lambda / d b^{*}\right)-V^{*} .
$$

Thus, the effect on real GDP depends on the change in the urban unemployedto-employed ratio $(\lambda)$ as well as the remittance effect, shown as $\left(-V^{*}\right)$. If the condition in Proposition 3 is satisfied, outsourcing decreases the urban unemployed-to-employed ratio (i.e., the term $d \lambda / d b^{*}$ is positive). Thus, from (28), it can be seen that outsourcing increases the real GDP of the home country. However, the effect becomes ambiguous if the condition is not satisfied. This is in sharp contrast to the case where there is no domestic production of the outsourced factor. With no domestic production, outsourcing always decreases the urban unemployed-to-employed ratio, and therefore definitely increases real GDP.

\section{Concluding Remarks}

In this paper, we have examined the effects of outsourcing on unemployment, factor rewards, and real GDP in an economy affected by urban unemployment. The main findings of this paper are as follows: (i) If the outsourced factor is not produced domestically, outsourcing increases the rural wage rate (and the expected urban wage rate) and decreases the unemployed-to-employed ratio in urban areas, and it may increase unemployment in the home country. (ii) If the outsourced 
factor is produced domestically, outsourcing may decrease the rural wage rate (and the expected urban wage rate), and may increase the unemployed-to-employed ratio in urban areas if the rural wage rate is not sensitive to the employment in the rural sectors. Thus, our results show that outsourcing may be detrimental to the home country both with and without domestic production of the outsourced factor. This paradoxical outcome is likely if the domestic workers are sensitive to the wage rate. This implies that domestic workers are interested in the "city lights" and want to move to urban areas in response to even a small increase in the expected urban wage.

The framework employed here may be extended to models with intersectorally mobile capital. Further, it is interesting to examine the issue under different kinds of distortion in the labor market-for example, a uniform fixed wage rate, differences between skilled and unskilled labor, and so on. These constitute important agenda for future work.

\section{Acknowledgements}

The author is grateful to an anonymous referee for the insightful comments. Financial support from the Japan Society for the Promotion of Science (Grants-inAid for Scientific Research, a-21243023 and c-19530210) is gratefully acknowledged.

Received 14 May 2011, Revised 18 October 2011, Accepted 20 October 2011

\section{References}

Basu, Kaushik. (2000), "Rural-Urban Migration, Urban Unemployment and the Structural Transformation of a Dual Economy," Journal of International Trade and Economic Development 9, 137-149.

Bardhan, Ashok and Cynthia A. Kroll. (2003), The New Wave of Outsourcing," Fisher Center for Real Estate \& Urban Economics Research Report Series No. 1103, Available at SSRN: http://ssrn.com/abstract=985741.

Batra, Ravi and Hamid Beladi. (2010a), "A Simple Two-Sector Model of Outsourcing," Review of Development Economics 14, 64-73.

Batra, Ravi and Hamid Beladi. (2010b), "Outsourcing and the Heckscher-Ohlin Model," Review of International Economics 18, 277-288.

Beladi, Hamid and Shigemi Yabuuchi. (2010), "Equity Control of Multinational Firms: Effects on Resource Allocation and National Welfare," Review of Development 
Economics 14, 93-102.

Bhagwati, Jagdish N. and T. N. Srinivasan. (1974), "On Reanalyzing the Harris-Todaro Model: Policy Rankings in the Case of Sector-Specific Sticky Wages," American Economic Review 64, 502-508.

Burke James, Gerald Epstein, and Minsik Choi. (2004), "Rising Foreign Outsourcing and Employment Losses in U.S. Manufacturing, 1987-2002," Political Economy Research Institute Working Paper No. 89, University of Massachusetts at Amherst, Available at SSRN: http://www.peri.umass.edu/fileadmin/pdf/working_papers/ working papers 51-100/WP89.pdf.

Chao, C. C. and E. S. H. Yu. (1996), "International Capital Mobility, Urban Unemployment and Welfare," Southern Economic Journal 62, 486-492.

Deardorff, Alan. (2005), "A Trade Theorist's Take on Skilled-Labor Outsourcing," International Review of Economics and Finance 14, 259-271.

Egger, Hartmut and Peter Egger. (2005), "Labor Market Effects of Outsourcing under Industrial Interdependence," International Review of Economics and Finance 14, 349-363.

Feenstra, Robert C. and Gordon H. Hanson. (1996), "Foreign Direct Investment, Outsourcing and Relative Wages," in Robert C. Feenstra, Gene M. Grossman, and D. A. Irwin (eds), The Political Economy of Trade Policy: Papers in Honor of Jagdish Bhagwati, Cambridge, MA: MIT Press, 89-127.

Gorg, Holger and Aoife Hanley. (2005), "Labor Demand Effects of International Outsourcing: Evidence from Plant-Level Data," International Review of Economics and Finance 14, 365-376.

Grossman, Gene and Elhanan Helpman. (2005), "Outsourcing in a Global Economy," Review of Economic Studies 72, 135-159.

Gupta, Manash Ranjan. (1993). "Rural-Urban Migration, Informal Sector, and Development Policies," Journal of Development Economics 41, 137-151.

Harris, John R. and Michael Todaro. (1970), "Migration, Unemployment, and Development: A Two-Sector Analysis," American Economic Review 60, 126-142.

Jones, Ronald W. (1971), "A Three-Factor Model in Theory, Trade and History," in J. N. Bhagwati et al. (eds.), Trade, Balance of Payments and Growth: Essays in Honor of C. P. Kindleberger, Amsterdam: North-Holland, 3-21.

Jones, Ronald W. (2005), "Immigration vs. Outsourcing: Effects on Labor Markets," International Review of Economics and Finance 14, 105-114.

Keuschnigg, Christian and Evelyn Ribi. (2009), "Outsourcing, Unemployment and Welfare Policy," Journal of International Economics 78, 168-176.

Khan, M. Ali. (1980), "Dynamic Stability, Wage Subsidies, and the Generalized HarrisTodaro Model," Pakistan Economic Review 19, 1-24.

Kierzkowski, Henryk. (2005), "Outsourcing and Fragmentation: Blessing or Threat?" International Review of Economics and Finance 14, 233-235.

Kohler, Wilhelm. (2001), "A Specific-Factors View on Outsourcing," North American Journal of Economics and Finance 12, 31-53. 
Long, Ngo Van. (2005), "Outsourcing and Technology Spilovers," International Review of Economics and Finance 14, 297-304.

Mankiw, N. Gregory, David Romer, and David N. Weil. (2004), "A Contribution to the Empirics of Economic Growth," Elgar Reference Collection. International Library of Critical Writings in Economics, Cheltenham: Edward Elgar, 163-193.

Marjit, Sugata and Hamid Beladi. (2003), "Possibility or Impossibility of Paradoxes in the Small Country Harris-Todaro Framework: A Unified Analysis," Journal of Developing Economics 72, 379-385.

Neary, Peter J. (1981), "On the Harris-Todaro Model with Intersectoral Capital Mobility," Economica 48, 219-234.

Swenson, Deborah L. (2005), "Overseas Assembly and Country Sourcing Choices," Journal of International Economics 66, 107-130.

Tomiura, Eiichi. (2005), "Foreign Outsourcing and Firm-Level Characteristics: Evidence from Japanese Manufacturers," Journal of the Japanese and International Economies 19, 255-271.

Yabuuchi, Shigemi. (1993), "Urban Unemployment, International Capital Mobility, and Development Policy," Journal of Development Economics 41, 399-403.

Zhu, Yiping. (2008), "Globalisation, Employment, and Wage Rate: What Does Literature Tell Us?” IMK (Institut fur Makrookonomie und Konjunkturforshung) Working paper No. 7.

\section{Appendix}

\section{A. Comparative statistics: Model without domestic production}

Totally differentiating (3)-(10) and arranging them in matrix form for the changes in the key variables, we have

$$
d \lambda / d b^{*}=-(1+\lambda)^{2} Y_{L L} p X_{L V} / \Delta>0
$$

where

$$
\Delta=\left\{w-L_{x}(1+\lambda) Y_{L L}\right\} H>0,
$$

Differentiating (4)-(12) and arranging terms with respect to the key variables, we obtain 


$$
\left[\begin{array}{ccccc}
p X_{L L} & 0 & p X_{L V} & 0 & 0 \\
0 & Y_{L L} & 0 & 0 & -1 \\
0 & 0 & 0 & w & (1+\lambda) \\
(1+\lambda) & 1 & 0 & L_{x} & 0 \\
p X_{V L} & 0 & p X_{V V} & 0 & 0
\end{array}\right]\left[\begin{array}{l}
d L_{x} \\
d L_{y} \\
d V_{x} \\
d \lambda \\
d w
\end{array}\right]=\left[\begin{array}{l}
0 \\
0 \\
0 \\
0 \\
1
\end{array}\right] d b^{*} .
$$

By solving (A1) for $\lambda$, the change in the price of the outsourced factor $b^{*}$, we obtain equation (11) in the main text as

$$
d \lambda / d b^{*}=-(1+\lambda)^{2} Y_{L L} p X_{L V} / \Delta>0,
$$

where

$$
\Delta=\left\{w-L_{x}(1+\lambda) Y_{L L}\right\} H>0,
$$

and $\Delta$ is the value of the determinant of the coefficient matrix of the equation system. Other equations are derived similarly.

\section{B. Comparative statistics: Model with domestic production}

Totally differentiating (3)-(5), (7)-(9), and (20)-(22) and arranging them in matrix form for the changes in the key variables, we have

$$
\left[\begin{array}{cccccc}
p X_{L L} & 0 & V_{L} X_{L V} & p X_{L V} & 0 & 0 \\
0 & Y_{L L} & 0 & 0 & 0 & -1 \\
0 & -Y_{L L} & b^{*} V_{L L} & 0 & 0 & 0 \\
0 & 0 & 0 & 0 & w & (1+\lambda) \\
(1+\lambda) & 1 & 1 & 0 & L_{x} & 0 \\
p X_{V L} & 0 & V_{L} X_{V V} & p X_{V V} & 0 & 0
\end{array}\right]\left[\begin{array}{c}
d L_{x} \\
d L_{y} \\
d L_{v} \\
d V^{*} \\
d \lambda \\
d w
\end{array}\right]=\left[\begin{array}{c}
0 \\
0 \\
-V_{L} \\
0 \\
0 \\
1
\end{array}\right] d b^{*}
$$

Similarly, by solving (A2) for the variables with respect to $b^{*}$, we obtain equations (23) to (27) in the text. 